\title{
A Determination of the Oxygen Non-stoichiometry of the Oxygen Storage Material $\mathrm{YBaMn}_{2} \mathrm{O}_{5+\delta}$
}

Kannika Jeamjumnunja, Wenquan Gong, Tatyana Makarenko, and Allan J. Jacobson*

Texas Center for Superconductivity and Department of Chemistry

University of Houston, Houston, TX 77204-5003, USA

* To whom correspondence should be addressed. Tel.: (+1) 7137432785. Fax: (+1) 7137432787.

E-mail: ajjacob@uh.edu. 


\begin{abstract}
The A-site ordered double-perovskite oxide, $\mathrm{YBaMn}_{2} \mathrm{O}_{5+\delta}$, has been of recent interest for possible application as an oxygen storage material. In the present study, the oxygen nonstoichiometry of $\mathrm{YBaMn}_{2} \mathrm{O}_{5+\delta}$ has been determined as a function of $\mathrm{pO}_{2}$ at 650,700 and $750{ }^{\circ} \mathrm{C}$ by Coulometric titration at near-equilibrium conditions. The results confirm that this perovskite oxide has three distinct phases on oxidation/reduction with $\delta \approx 0,0.5$ and 1 . The stabilities of the $\mathrm{YBaMn}_{2} \mathrm{O}_{5+\delta}$ phases span a wide range of oxygen partial pressures $\left(\sim 10^{-20} \leq \mathrm{pO}_{2}(\mathrm{~atm}) \leq \sim 1\right.$ atm $)$ depending on temperature. The phases interconvert at higher $\mathrm{pO}_{2}$ values at higher temperatures. The partial molar free energies $\left(\Delta \mu_{\mathrm{O}}\right)$ corresponding to the oxidation of $\mathrm{YBaMn}_{2} \mathrm{O}_{5}$ to $\mathrm{YBaMn}_{2} \mathrm{O}_{5.5}$ and of $\mathrm{YBaMn}_{2} \mathrm{O}_{5.5}$ to $\mathrm{YBaMn}_{2} \mathrm{O}_{\sim 6}$ were determined. The value of $\Delta \mu_{\mathrm{O}}$ in both oxidation steps becomes less negative with increasing temperature. At some $\mathrm{T}$ and $\mathrm{pO}_{2}$ conditions, $\mathrm{YBaMn}_{2} \mathrm{O}_{5+\delta}$ is unstable with respect to decomposition to $\mathrm{BaMnO}_{3-\delta}$ and $\mathrm{YMnO}_{3}$. This instability is anticipated from the previous studies of the synthesis of $\mathrm{YBaMn}_{2} \mathrm{O}_{5+\delta}$ but is more apparent in the present experiments which are necessarily slow in order to achieve equilibrium with respect to the oxygen content.
\end{abstract}

Keywords: Oxygen storage material; double perovskite oxide, yttrium barium manganese oxide; oxygen non-stoichiometry. 


\section{Introduction}

Non-stoichiometric oxides which are capable of rapidly and reversibly storing and releasing large amounts of oxygen gas are often called oxygen storage materials (OSMs) or oxygen carriers. These materials are of interest for applications including oxygen enrichment, oxygen separation, syngas production, and catalytic oxidation of hydrocarbons and small molecules. ${ }^{1-3}$ Among these applications, chemical looping has recently been suggested as a new technology for clean energy production from coal, partial oxidation of methane, and air separation. ${ }^{4-6}$ The availability of suitable oxygen storage materials is a crucial factor for application of this technology.

An ideal oxygen storage material should have the following properties: 1) a large oxygen storage capacity (OSC) stored as mobile oxygen ions in the crystal lattice; 2) the uptake/release of oxygen gas should be fast and reversible over a narrow temperature range; 3) adequate phase stability under operating conditions; 4) low operating temperature. ${ }^{4,7}$ The best known and most widely used OSMs are the $\mathrm{Ce}_{1-\mathrm{x}} \mathrm{Zr}_{\mathrm{x}} \mathrm{O}_{2-\delta}$ compositions with the fluorite structure which have oxygen storage capacities as high as $\sim 1500 \mu \mathrm{mol}-\mathrm{O} / \mathrm{g} .{ }^{8}$ They have been the materials of choice for three way catalysts, air separation, and selective oxidation of methane and have been investigated for solar thermochemical water splitting. ${ }^{1,-16}$ The properties of a number of other oxides have been investigated recently as candidate materials for oxygen storage with reference to the criteria outlined above. Some examples are given in Table 1. Of these, $\mathrm{YBaCo}_{4} \mathrm{O}_{7+\delta}$ has a markedly higher oxygen storage capacity than that of the $\mathrm{Ce}_{1-\mathrm{x}} \mathrm{Zr}_{\mathrm{x}} \mathrm{O}_{2-\delta}$, but decomposes on heating in an $\mathrm{O}_{2}$ atmosphere above $600{ }^{\circ} \mathrm{C}$. Its phase stability can be improved by partial substitution of Co with $\mathrm{Al}$ and $\mathrm{Ga}$, though with a decrease in the oxygen storage capacity. ${ }^{7}$ 
The oxide $\mathrm{YBaMn}_{2} \mathrm{O}_{5+\delta}$ with the double perovskite structure has the next highest oxygen storage capacity and reversible oxygen uptake/release characteristics and fast kinetics below 500 ${ }^{\circ} \mathrm{C}$. The theoretical oxygen storage capacity of the $\mathrm{YBaMn}_{2} \mathrm{O}_{5}-\mathrm{YBaMn}_{2} \mathrm{O}_{6}$ system is $\sim 2400 \mu$ mol$\mathrm{O} / \mathrm{g}$ or $\sim 3.85 \mathrm{wt} \%$. The stability of $\mathrm{YBaMn}_{2} \mathrm{O}_{5+\delta}$ has been demonstrated by cycling the compound between $\mathrm{O}_{2}$ and $5 \% \mathrm{H}_{2} / 95 \%$ Ar at $500{ }^{\circ} \mathrm{C}$ for over 100 cycles with no detectable decrease in efficiency. $\mathrm{YBaMn}_{2} \mathrm{O}_{5+\delta}$ was tested also as a catalyst for $\mathrm{CH}_{4}$ oxidation. Oxidation of $\mathrm{CH}_{4}$ began at around $450{ }^{\circ} \mathrm{C}$ and was complete at $550-600{ }^{\circ} \mathrm{C} .{ }^{21}$ Based on the previous work, the possibility of using $\mathrm{YBaMn}_{2} \mathrm{O}_{5+\delta}$ in a chemical looping application gave us an interest in further studying this system. The oxygen uptake/release kinetics of $\mathrm{YBaMn}_{2} \mathrm{O}_{5+\delta}$ have been studied by Motohashi et al., who also determined the $\mathrm{pO}_{2}$ dependence of the inter-conversion of $\mathrm{YBaMn}_{2} \mathrm{O}_{5.5}$ and $\mathrm{YBaMn}_{2} \mathrm{O}_{\sim 6}$ by thermogravimetric analysis in the $\mathrm{pO}_{2}$ range $10 \mathrm{~Pa}$ to $10^{5} \mathrm{~Pa}\left(10^{-4}\right.$ to $\left.1 \mathrm{~atm}\right)$ and also the range of composition of ' $\mathrm{O}_{6},{ }^{22-24}$ We note also that systems with $\mathrm{Y}$ partially or completely substituted with other rare-earth elements ( $\mathrm{La}, \mathrm{Pr}, \mathrm{Nd}, \mathrm{Sm}, \mathrm{Eu}, \mathrm{Gd}, \mathrm{Tb}, \mathrm{Dy}, \mathrm{Ho}$, and Er) have been investigated. ${ }^{25-44}$

Table 1: Structure type, oxygen storage capacity (OSC) and oxygen uptake/release conditions of some oxygen storage materials.

\begin{tabular}{|c|c|c|c|}
\hline Compound & Type of structure & $\begin{array}{c}\text { OSC } \\
(\mu \mathrm{mol}-\mathrm{O} / \mathrm{g})\end{array}$ & $\begin{array}{c}\text { Temperature and atmosphere for oxygen } \\
\text { uptake/release processes }\end{array}$ \\
\hline $\mathrm{Ce}_{1-\mathrm{x}} \mathrm{Zr}_{\mathrm{x}} \mathrm{O}_{2-\delta}{ }^{8}$ & Fluorite & $\sim 1500$ & $\begin{array}{l}\text { Oxidation in oxygen atmosphere and reversible } \\
\text { reduction in } 20 \% \mathrm{H}_{2} \text { at } 500{ }^{\circ} \mathrm{C}\end{array}$ \\
\hline $\mathrm{YBaCo}_{4} \mathrm{O}_{7+\delta}{ }^{17}$ & Hexagonal & 2700 & $\begin{array}{l}\text { Oxidation at } 200 \sim 400{ }^{\circ} \mathrm{C} \text { and reduction at } 400 \sim 425 \\
{ }^{\circ} \mathrm{C} \text { both in } \mathrm{O}_{2}\end{array}$ \\
\hline $\mathrm{Dy}_{1-\mathrm{x}} \mathrm{Y}_{\mathrm{x}} \mathrm{MnO}_{3+\delta}{ }^{18}$ & Hexagonal & 1200 & $\begin{array}{l}\text { Oxidation under high pressure oxygen at } 500{ }^{\circ} \mathrm{C} \text { and } \\
\text { reduction in } \mathrm{H}_{2} \text { at } 400{ }^{\circ} \mathrm{C}\end{array}$ \\
\hline $\mathrm{Ca}_{2} \mathrm{AlMnO}_{5+\delta}{ }^{19}$ & Brownmillerite & $\sim 1900$ & Reversible oxygen intake/release at $500 \sim 700{ }^{\circ} \mathrm{C}$ in $\mathrm{O}_{2}$ \\
\hline $\mathrm{LuFe}_{2} \mathrm{O}_{4+\delta}{ }^{20}$ & $\begin{array}{l}\text { Layered structure of } \\
\text { alternating }\left[\mathrm{LuO}_{2}\right] \\
\text { and }\left[\mathrm{Fe}_{2} \mathrm{O}_{4}\right] \text { layers }\end{array}$ & $\sim 1400$ & $\begin{array}{l}\text { Oxidation at } 200-500{ }^{\circ} \mathrm{C} \text { under an oxygen pressure of } \\
\sim 0.2 \times 10^{-3} \text { atm and reduction in } \mathrm{H}_{2} \text { from } 500{ }^{\circ} \mathrm{C}\end{array}$ \\
\hline $\mathrm{YBaMn}_{2} \mathrm{O}_{5+\delta}{ }^{21}$ & Double Perovskite & $\sim 2400$ & $\begin{array}{l}\text { Oxidation at } 200 \sim 390{ }^{\circ} \mathrm{C} \text { in } \mathrm{O}_{2} \text { and reduction at } \\
200 \sim 490{ }^{\circ} \mathrm{C} \text { under } 5 \% \mathrm{H}_{2} / 95 \% \text { Ar atmosphere }\end{array}$ \\
\hline
\end{tabular}


In the present work, the non-stoichiometry of $\mathrm{YBaMn}_{2} \mathrm{O}_{5+\delta}$ has been determined by Coulometric titration in sealed electrochemical cells under near equilibrium conditions. Oxygen non-stoichiometry $(\delta)$ was measured over a wide range of oxygen partial pressures $\left(\sim 10^{-20} \leq \mathrm{pO}_{2}\right.$ $\leq \sim 1$ atm) at 650,700 , and $750{ }^{\circ} \mathrm{C}$, providing both thermodynamic and kinetic data.

\section{Experimental section}

2.1 Synthesis: As previously reported, the synthesis of the double perovskite oxide $\mathrm{YBaMn}_{2} \mathrm{O}_{5+\delta}$ must be carried out in a low oxygen partial pressure to prevent the formation of $\mathrm{BaMnO}_{3-\delta .}{ }^{45-49}$ Polycrystalline $\mathrm{YBaMn}_{2} \mathrm{O}_{5+\delta}$ was synthesized via a solid state reaction under a mixture of dry $\mathrm{N}_{2}$ and a water-saturated $5 \% \mathrm{H}_{2} / 95 \%$ Ar gas mixture $\left(\mathrm{pO}_{2} \approx 10^{-12}\right.$ atm). As a precursor, a stoichiometric mixture of $\mathrm{BaCO}_{3}$ (Aldrich 99.999\%), $\mathrm{Y}_{2} \mathrm{O}_{3}$ (Aldrich 99.99\%) and $\mathrm{Mn}_{2} \mathrm{O}_{3}($ Aldrich 99\%) was ball-milled in isopropanol for $24 \mathrm{~h}$ and then dried in an oven for $48 \mathrm{~h}$. About $200 \mathrm{mg}$ of the ball-milled precursor powder was sintered in a tube furnace at $1050{ }^{\circ} \mathrm{C}$ for $22 \mathrm{~h}$ in the flowing gas mixture described above, and then rapidly cooled to room temperature. The $\mathrm{YBaMn}_{2} \mathrm{O}_{5}$ product was annealed at $800{ }^{\circ} \mathrm{C}$ for $12 \mathrm{~h}$ in flowing $\mathrm{O}_{2}$ gas with $2{ }^{\circ} \mathrm{C} / \mathrm{min}$ heating and cooling rates to obtain fully-oxidized $\mathrm{YBaMn}_{2} \mathrm{O}_{5+\delta}$. The half-reduced sample (' $\mathrm{O}_{5.5}$ ') was prepared by annealing the fully-oxidized powder under $\mathrm{N}_{2}$ atmosphere at $700{ }^{\circ} \mathrm{C}$ for $12 \mathrm{~h}$ with $1{ }^{\circ} \mathrm{C} / \mathrm{min}$ heating rate, followed by fast cooling to room temperature ( $\square 20^{\circ} \mathrm{C} / \mathrm{min}$ ).

\subsection{The Oxygen Non-Stoichiometry as a function of $\mathrm{T}$ and $\mathrm{pO}_{2}$ :}

The oxygen non-stoichiometry of $\mathrm{YBaMn}_{2} \mathrm{O}_{5+\delta}$ was determined by Coulometric titration as a function of $\mathrm{pO}_{2}$ at three temperatures 650,700 , and $750{ }^{\circ} \mathrm{C}$. The experimental method we used has been reported previously and is only briefly reviewed here. ${ }^{50,51}$ The Coulometric titration cell is composed of an electrolyte (8-wt\% polycrystalline yttria-stabilized zirconia (YSZ) disk), two 
alumina rings, three glass rings and alumina container. The YSZ disk with Pt mesh electrodes was connected to Pt wires and placed on the top of the titration cell. This YSZ disk was used for pumping oxygen in/out of the cell and also as an oxygen sensor. A Keithley 2400 SourceMeter was used to provide the pump current and to monitor the EMF of the sensor. Air was used as the reference gas. The Pt wires connected to the YSZ disk were brought out of the cell via glass rings. The gas-tight seals were made by heating the cell above the softening temperature of the glass rings $\left(\sim 750{ }^{\circ} \mathrm{C}\right)$. The height of cell was $\sim 15 \mathrm{~mm}$ after sealing. An R-type thermocouple was used for monitoring temperature and the experiments were controlled by using LabView software.

The oxygen partial pressure $\left(\mathrm{pO}_{2}\right)$ inside the cell is given by the Nernst equation $E=-$ $\mathrm{RT} / 4 \mathrm{~F} \cdot \ln \left(\mathrm{pO}_{2}{ }^{\text {cell }} / \mathrm{pO}_{2}{ }^{\text {ref }}\right)$ where $\mathrm{pO}_{2}{ }^{\text {cell }}$ and $\mathrm{pO}_{2}{ }^{\text {ref }}$ are the oxygen partial pressure inside the cell and of the reference gas, respectively, $\mathrm{F}$ is the Faraday constant, $E$ is the cell $E M F$, and $\mathrm{R}$ is the gas constant. The non-stoichiometry change $(\Delta \delta)$ was determined in the range $\sim 10^{-20} \leq \mathrm{pO}_{2}($ atm $) \leq$ $\sim 1$ at 650,700 and $750{ }^{\circ} \mathrm{C}$. A change in the sensor voltage of less than $0.001 \%$ per minute was chosen as the criterion for equilibrium. All titration experiments at each temperature were performed on both decreasing and increasing $\mathrm{pO}_{2}$. The oxygen flux into and out of the cell is controlled by applying a current for a given time. ${ }^{52}$ Thus the variation of number of moles of oxygen transferred by pumping is given by Faraday's law: $\Delta n_{O_{2}, \text { total }}=\mathrm{i} \cdot \mathrm{t} / 4 \mathrm{~F}$ where, $\mathrm{i}$ is the applied current, $\mathrm{t}$ is the pumping time, and $\mathrm{F}$ is the Faraday constant. The change in the total number of moles of oxygen is the sum of the changes in number of moles in the sample and the free space: $\Delta n_{\mathrm{O}_{2}, \text { total }}=\Delta n_{\mathrm{O}_{2} \text {,sample }}+\Delta n_{\mathrm{O}_{2} \text {,space. }}$. The value of $\Delta n_{\mathrm{O}_{2} \text {,space }}$ was calculated assuming ideal gas behavior. The cell volume is made as small as possible to minimize the correction. The change of oxygen stoichiometry $(\Delta \delta)$ of the sample is expressed by the following 
equation: $\Delta \delta=2 M / W \cdot \Delta n_{O_{2}, \text { sample }}$ where, $M$ and $W$ are the molecular weight and the weight of the sample. The change of oxygen stoichiometry $(\Delta \delta)$ of the sample is then given by:

$$
\Delta \delta=\frac{2 M}{W} \cdot \Delta n_{O_{2, \text { sample }}}=\frac{2 M}{W} \cdot\left(\Delta n_{O_{2, \text { total }}}-\Delta n_{O_{2, \text { space }}}\right)=\frac{2 M}{W}\left\{\left(\frac{i t}{4 F}\right)-\left(\frac{\Delta P V}{R T}\right)\right\}
$$

In addition, a small correction is made for the oxygen leakage flux $\left(J_{o}\right)$ through 8-mol \% YSZ due to a small electronic contribution to the conductivity at low $\mathrm{pO}_{2}$ using previous results. ${ }^{53}$

\subsection{Characterization:}

2.2.1 Phase purity: The phase purity of the samples was verified using powder X-ray diffraction (XRD) with a Phillips PANalytical X'Pert PRO diffractometer with Cu K $\alpha$ radiation ( $\lambda=1.54046$ $\AA$ ) at room temperature. The lattice parameters were determined through Le Bail refinement using the GSAS/EXPGUI program.

2.2.2 Chemical Analysis: The precise oxygen content of the samples was obtained by iodometric

titration. ${ }^{47}$ Approximately $30 \mathrm{mg}$ of the finely ground sample powder was dissolved in $20 \mathrm{ml}$ of $20 \% \mathrm{KI}$ solution and $2 \mathrm{ml}$ of concentrated $\mathrm{HCl}$ under a $\mathrm{N}_{2}$ atmosphere. The amount of $\mathrm{I}_{2}$ formed in the reduction reaction of $\mathrm{Mn}^{3+}$ and/or $\mathrm{Mn}^{4+}$ to $\mathrm{Mn}^{2+}$ ion was titrated with $0.02 \mathrm{M} \mathrm{Na}_{2} \mathrm{~S}_{2} \mathrm{O}_{3}$ solution in the presence of a starch indicator. Without the sample, the same amount of KI solution and concentrated $\mathrm{HCl}$ was used in a control experiment. Each experiment was repeated for 3 times with good reproducibility.

2.2.3 Thermogravimetric Analysis: The oxygen uptake/release characteristics of the products were investigated on TA Instruments Hi-Res 2950 thermogravimetric analyzer. For the oxygen uptake study, approximately $40 \mathrm{mg}$ of the as-synthesized $\mathrm{YBaMn}_{2} \mathrm{O}_{5+\delta}$ powder was heated and then cooled in a platinum sample pan between room temperature and $800{ }^{\circ} \mathrm{C}$ at $2{ }^{\circ} \mathrm{C} / \mathrm{min}$ in flowing $\mathrm{O}_{2}$ gas. Subsequently, in order to investigate oxygen release process, the oxidized 
$\mathrm{YBaMn}_{2} \mathrm{O}_{5+\delta}$ sample was heated and cooled under a flowing $\mathrm{N}_{2}$ atmosphere in the same temperature range with a rate of $2{ }^{\circ} \mathrm{C} / \mathrm{min}$ and $20^{\circ} \mathrm{C} / \mathrm{min}$, respectively.

\section{Results and discussion}

\subsection{Characterization}

The control of the oxygen partial pressure is known to be a crucial factor for the synthesis of $\mathrm{YBaMn}_{2} \mathrm{O}_{5+\delta}$ with $\delta=0$. The compound is formed only under reducing conditions. Polycrystalline $\mathrm{YBaMn}_{2} \mathrm{O}_{5}$ was synthesized by solid state reaction at $\mathrm{pO}_{2} \approx 10^{-12}$ atm and 1050 ${ }^{\circ} \mathrm{C}$. The product was annealed in $\mathrm{O}_{2}$ and then in $\mathrm{N}_{2}$ to obtain fully-oxidized $\mathrm{YBaMn}_{2} \mathrm{O}_{6}$ and halfreduced $\mathrm{YBaMn}_{2} \mathrm{O}_{5.5}$ phases, respectively as described previously. ${ }^{21,24,47,54}$ The crystal structure of $\mathrm{YBaMn}_{2} \mathrm{O}_{5+\delta}$ can be described as an A-site ordered double-perovskite with alternating layers of yttrium and barium ions at the perovskite A-site as previous reported. ${ }^{24,47,49}$ The three phases $\left(\mathrm{O}_{5}\right.$, $\mathrm{O}_{5.5}$ and $\mathrm{O}_{\sim 6}$ ) of $\mathrm{YBaMn}_{2} \mathrm{O}_{5+\delta}$ differ in the occupancy of the oxygen atom site within the yttrium atom layer.

The lattice parameters for all of the samples are shown in Table 2. They were single phase, except for one very weak diffraction peak unindexed at $\sim 29.5^{\circ}$ attributed to the trace of $\mathrm{Y}_{2} \mathrm{O}_{3}$ impurity. The diffraction peaks of $\mathrm{YBaMn}_{2} \mathrm{O}_{5}$ were indexed on the basis of the tetragonal space group, P4/nmm, giving lattice parameters in good agreement with those in the literature. ${ }^{47}$ According to precise neutron diffraction studies reported by Williams et $a l^{55}$, the oxidized $\mathrm{YBaMn}_{2} \mathrm{O}_{6}$ has a triclinic $\mathrm{P}-1$ space group. In the present work, the $\mathrm{X}$-ray data were refined in the monoclinic space group P2 with the lattice parameters consistent with those previously reported. ${ }^{47}$ Nothing in the X-ray data justified lowering the symmetry further. For the $\mathrm{N}_{2}$-annealed product, the diffraction pattern of $\mathrm{YBaMn}_{2} \mathrm{O}_{5.5}$ was refined based on an orthorhombic Icma structure, with 
lattice parameters close to those reported by Perca et al. ${ }^{49}$ The refined data for $\mathrm{YBaMn}_{2} \mathrm{O}_{5.5}$ are shown in Figure 1 as a representative example.

Table 2: Structural parameters of reduced and oxidized $\mathrm{YBaMn}_{2} \mathrm{O}_{5+\delta}$ oxides

\begin{tabular}{|c|c|c|c|c|c|c|c|}
\hline Composition & $\begin{array}{l}\text { Space } \\
\text { group }\end{array}$ & a $(\AA)$ & b $(\AA)$ & c $(\AA)$ & Volume $\left(\AA^{3}\right)$ & $\chi^{2}$ & $\begin{array}{c}\text { wRp } \\
(\%)\end{array}$ \\
\hline $\begin{array}{l}\mathrm{YBaMn}_{2} \mathrm{O}_{5} \\
\mathrm{YBaMn}_{2} \mathrm{O}_{5.5} \\
\mathrm{YBaMn}_{2} \mathrm{O}_{6}\end{array}$ & $\begin{array}{l}\text { P4/nmm } \\
\text { Icma } \\
\text { P2 }\end{array}$ & $\begin{array}{l}5.5494(1) \\
8.1590(1) \\
5.5247(1)\end{array}$ & $\begin{array}{l}7.5452(1) \\
5.5192(1) \\
\beta=90.299(0)\end{array}$ & $\begin{array}{l}7.6522(1) \\
15.2731(2) \\
7.6085(1)\end{array}$ & $\begin{array}{l}235.66(1) \\
940.29(2) \\
232.00(1)\end{array}$ & $\begin{array}{l}2.12 \\
3.65 \\
1.48\end{array}$ & $\begin{array}{l}6.14 \\
6.66 \\
3.74\end{array}$ \\
\hline
\end{tabular}

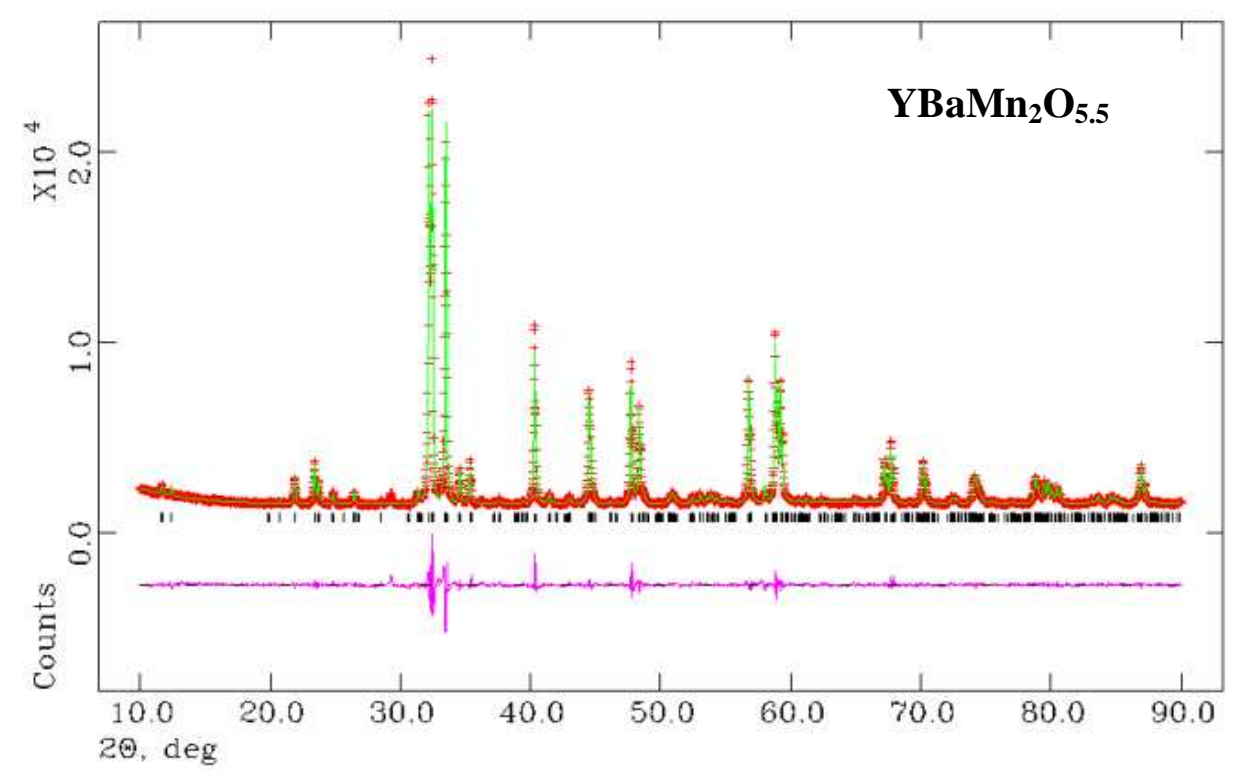

Figure 1: $\mathrm{X}$-ray data for $\mathrm{YBaMn}_{2} \mathrm{O}_{5.5}$. The measured data are shown in red, the calculated data are shown in green, and the difference is shown in pink. Bragg reflections are shown by vertical tick marks.

For comparison with previous work, the oxygen uptake/release characteristics of the present $\mathrm{YBaMn}_{2} \mathrm{O}_{5+\delta}$ compounds were determined by thermogravimetry. The oxygen content of the assynthesized $\mathrm{YBaMn}_{2} \mathrm{O}_{5+\delta}$ determined by iodometric titration corresponded to $\delta=-0.002(1)$. A 
sample of $\mathrm{YBaMn}_{2} \mathrm{O}_{4.998}$ was heated and then cooled in $\mathrm{O}_{2}$ flowing between 25 and $800{ }^{\circ} \mathrm{C}$ at a rate of $2{ }^{\circ} \mathrm{C} / \mathrm{min}$. The TGA data (Fig. 2(a)) show that a weight gain occurs in a single sharp step between $\sim 225{ }^{\circ} \mathrm{C}$ to $\sim 375{ }^{\circ} \mathrm{C}$. The weight gain of 3.59 wt $\%$ corresponds to $\delta=0.93$ (i.e. $\left.\mathrm{YBaMn}_{2} \mathrm{O}_{5.93}\right)$. This magnitude of the weight gain is close to the value $(3.85 \mathrm{wt} \%)$ expected to obtain a fully oxidized $\mathrm{YBaMn}_{2} \mathrm{O}_{5+\delta}$ (with $\delta=1$ ). The product from a parallel experiment in a tube furnace was shown to be the ' $\mathrm{O}_{6}$ ' phase by $\mathrm{X}$-ray powder diffraction. Subsequently, after cooling to ambient temperature, $\mathrm{YBaMn}_{2} \mathrm{O}_{5.93}$ was heated to $800{ }^{\circ} \mathrm{C}$ under $\mathrm{N}_{2}\left(\mathrm{pO}_{2} \approx 10^{-4}\right.$ atm $)$ at $2{ }^{\circ} \mathrm{C} /$ min heating rate, followed by fast cooling $\left(20^{\circ} \mathrm{C} / \mathrm{min}\right)$ to room temperature.
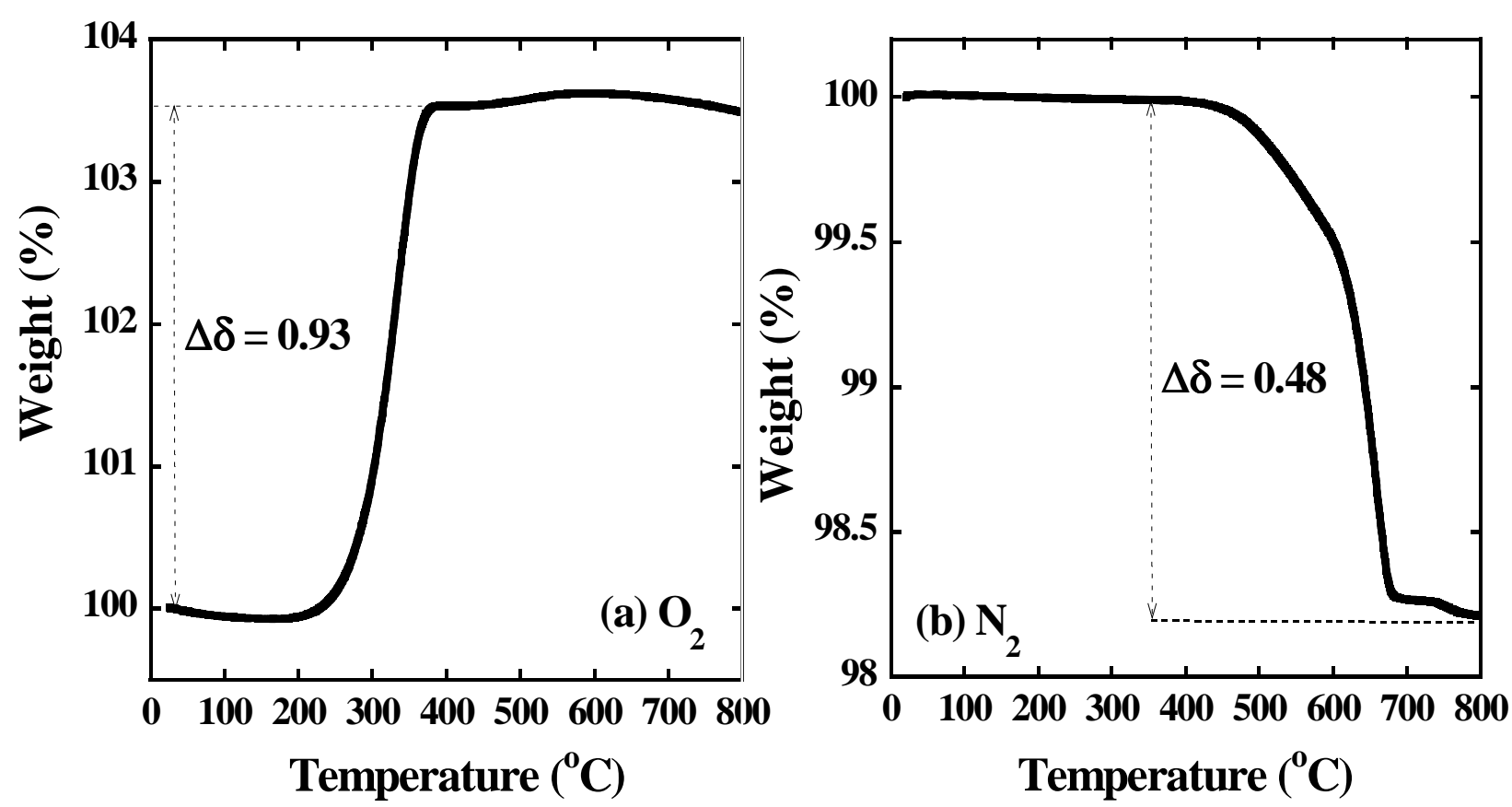

Figure 2: Thermogravimetric analysis of $\mathrm{YBaMn}_{2} \mathrm{O}_{5+\delta}$; (a) The ' $\mathrm{O}_{5}$ ' phase was heated from room temperature up to $800{ }^{\circ} \mathrm{C}$ in $\mathrm{O}_{2}$ flow; (b) The resulting oxidized product was subsequently heated under $\mathrm{N}_{2}$ up to $800{ }^{\circ} \mathrm{C}$.

From the TGA data (Fig. 2(b)), the oxygen release occurs between $400{ }^{\circ} \mathrm{C}$ and $800{ }^{\circ} \mathrm{C}$ in a single step. The $1.79 \%$ weight loss, corresponding to $\delta=0.48$ (i.e. $\mathrm{YBaMn}_{2} \mathrm{O}_{5.45}$ ). The $\mathrm{XRD}$ 
pattern of the reduced phase contains only the diffraction lines which are characteristic of the $\mathrm{O}_{5.5}$

phase. Reduction of $\mathrm{YBaMn}_{2} \mathrm{O}_{5+\delta}$ under $\mathrm{N}_{2}\left(\mathrm{pO}_{2} \approx 10^{-4}\right.$ atm) involves only $\mathrm{O}_{6}$ and $\mathrm{O}_{5.5}$ phases while only the $\mathrm{O}_{5}$ and $\mathrm{O}_{6}$ phases are observed on oxidation. In general, these results are similar to those reported previously. ${ }^{21,47}$

\subsection{Coulometric Titration}

The oxygen non-stoichiometry $(\delta)$ of $\mathrm{YBaMn}_{2} \mathrm{O}_{5+\delta}$ was measured as a function of oxygen partial pressure $\left(\mathrm{pO}_{2}\right)$ using Coulometric titration. Measurements were made in sealed electrochemical cells at $\sim 10^{-20} \leq \mathrm{pO}_{2} \leq \sim 1$ atm on both decreasing and increasing $\mathrm{pO}_{2}$. The dependences of the oxygen non-stoichiometry of $\mathrm{YBaMn}_{2} \mathrm{O}_{5+\delta}$ on $\mathrm{pO}_{2}$ at 650,700 and $750{ }^{\circ} \mathrm{C}$ are shown in Figure 3 (a-c), respectively. As expected, three distinct phases are apparent in the variation of the oxygen content with $\mathrm{pO}_{2}$. At $650{ }^{\circ} \mathrm{C}$, two phases have narrow ranges of composition with oxygen contents $(5+\delta)=4.99-5.02$ and 5.46-5.54. The most oxidized phase has a significant range of composition from 5.84-5.95 at $650{ }^{\circ} \mathrm{C}$ as shown in Fig. 3 (a). Similar behavior in $\mathrm{YBaMn}_{2} \mathrm{O}_{5+\delta}$ also occurs at higher temperatures, 700 and $750^{\circ} \mathrm{C}$, as presented in Fig. $3(\mathrm{~b}-\mathrm{c})$, but the transitions between the phases shift to higher $\mathrm{pO}_{2}$ at higher temperature. The composition ranges of each phase and the $\mathrm{pO}_{2}$ of phase inter-conversion are summarized in Table 3. Note that on reoxidation, steps in the data occur at $-\log \mathrm{pO}_{2}=7.35,7.71$, and 7.77 at 650,700 , and $750{ }^{\circ} \mathrm{C}$ (Fig. 3(a-c)), respectively due to some decomposition (see below for further discussion). Consequently some uncertainty exists concerning the upper value of the oxygen content because the experiments were carried out in the temperature sequence $650 \rightarrow 700 \rightarrow 750{ }^{\circ} \mathrm{C}$ and some decomposition occurred during reoxidation from $650{ }^{\circ} \mathrm{C}$ before the reduction experiment at $700{ }^{\circ} \mathrm{C}$ and similarly during reoxidation at $700{ }^{\circ} \mathrm{C}$ before the reduction experiment at $750{ }^{\circ} \mathrm{C}$. This has a small effect on the upper value of the oxygen content because the average Mn oxidation state for $\mathrm{YBaMn}_{2} \mathrm{O}_{6}$ and the 
phase separated products is the same at high $\mathrm{pO}_{2}(\sim 1 \mathrm{~atm})$. The value of $\mathrm{pO}_{2}$ at which $5.5+\delta$ converts to 5.5 is not effected and the values scale linearly with temperature (Figure 4).

Table 3: Composition ranges of each phase and the $\mathrm{pO}_{2}$ of phase inter-conversion in $\mathrm{YBaMn}_{2} \mathrm{O}_{5+\delta}$ at 650,700 and $750{ }^{\circ} \mathrm{C}$.

\begin{tabular}{|c|c|c|c|c|c|}
\hline $\begin{array}{c}\text { Temperature } \\
\left({ }^{\circ} \mathbf{C}\right)\end{array}$ & $\begin{array}{c}\mathrm{O}_{5} \text { phase } \\
\text { composition } \\
\text { range }\end{array}$ & $\begin{array}{c}-\log \mathrm{pO}_{2} \text { of the } \\
\text { transition between } \\
\mathrm{O}_{5} \text { and } \mathrm{O}_{5.5}\end{array}$ & $\begin{array}{c}\mathrm{O}_{5.5} \text { phase } \\
\text { composition } \\
\text { range }\end{array}$ & $\begin{array}{c}-\log \mathrm{pO}_{2} \text { of the } \\
\text { transition between } \\
\mathrm{O}_{5.5} \text { and } \mathrm{O}_{6}\end{array}$ & $\begin{array}{c}\mathrm{O}_{6} \text { phase } \\
\text { composition } \\
\text { range* }\end{array}$ \\
\hline 650 & $4.99-5.02$ & 14.82 & $5.46-5.54$ & 3.23 & $5.84-5.95$ \\
\hline 700 & $5.00-5.07$ & 13.41 & $5.47-5.55$ & 2.83 & $5.83-5.95$ \\
\hline 750 & $4.99-5.11$ & 12.18 & $5.43-5.54$ & 2.51 & $5.75-5.87$ \\
\hline
\end{tabular}

* Some uncertainty exists concerning the upper value of the oxygen content (see text).

The $\mathrm{pO}_{2}$ dependence on temperature of $\mathrm{O}_{5}$ to $\mathrm{O}_{5.5}$ and $\mathrm{O}_{5.5}$ to $\mathrm{O}_{6}$ phase transition is shown in Figure 4. The present results for the $\mathrm{O}_{5.5}$ to $\mathrm{O}_{6}$ inter-conversion can be compared with the recent TGA measurements of Motohashi et al. ${ }^{22}$ Based on their results, the $\mathrm{pO}_{2}$ of the transition between $\mathrm{O}_{5.5}$ and $\mathrm{O}_{6}$ phases occurred approximately at $-\log \mathrm{pO}_{2}=3.40,2.71,2.46$ at 650,700 and $750{ }^{\circ} \mathrm{C}$, respectively, in good agreement with the present data given in Table 3.
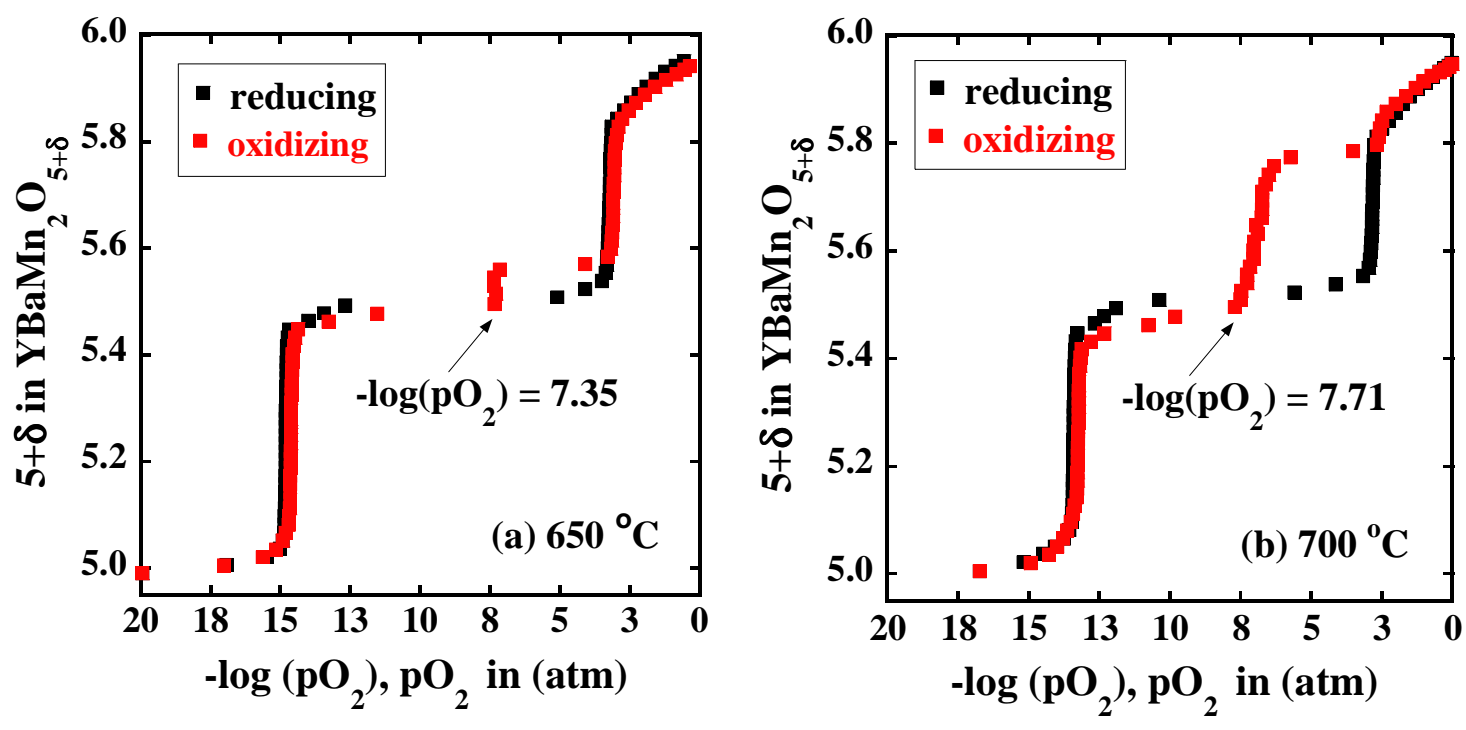


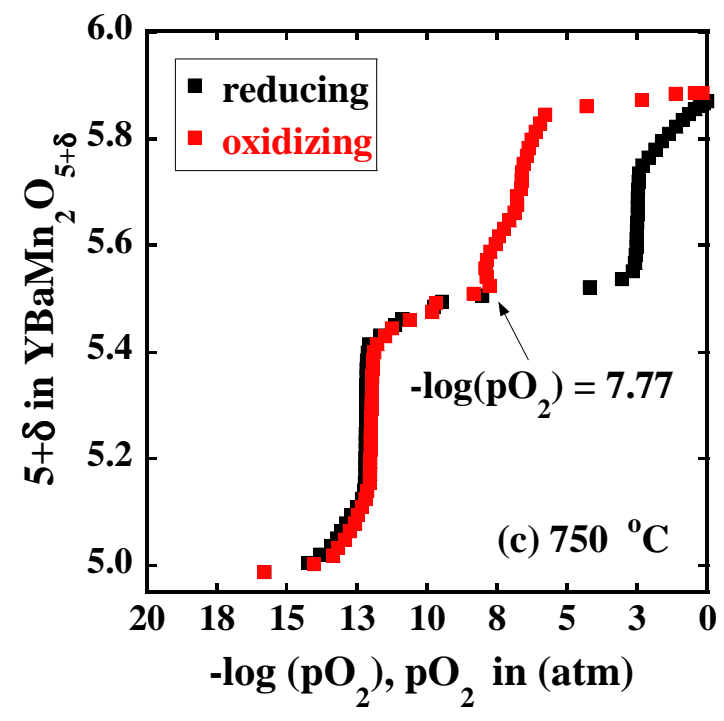

Figure 3: The $\mathrm{pO}_{2}$ dependence of oxygen-non stoichiometry on $\mathrm{pO}_{2}$ measured on reduction and reoxidation of $\mathrm{YBaMn}_{2} \mathrm{O}_{5+\delta}$ at (a) $650{ }^{\circ} \mathrm{C}$, (b) $700{ }^{\circ} \mathrm{C}$ and (c) $750{ }^{\circ} \mathrm{C}$.

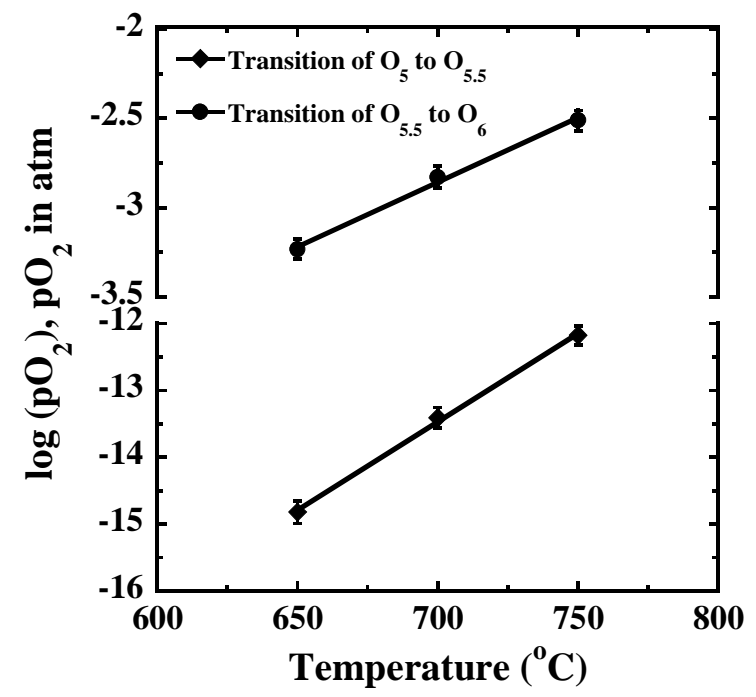

Figure 4: The temperature dependence of the $\mathrm{pO}_{2}$ corresponding to the transitions from $\mathrm{O}_{5}$ to $\mathrm{O}_{5.5}$ and $\mathrm{O}_{5.5}$ to $\mathrm{O}_{5.5+\delta}$. The data were measured on reduction.

\subsection{Kinetic Effects and Phase Stability}


With the chosen criterion for equilibrium ( $0.001 \%$ change in the sensor voltage per minute) different kinetic regimes were observed. As an example, the equilibrium times for oxidation and reduction are shown in Figure 5 as a function of oxygen non-stoichiometry at $650{ }^{\circ} \mathrm{C}$.

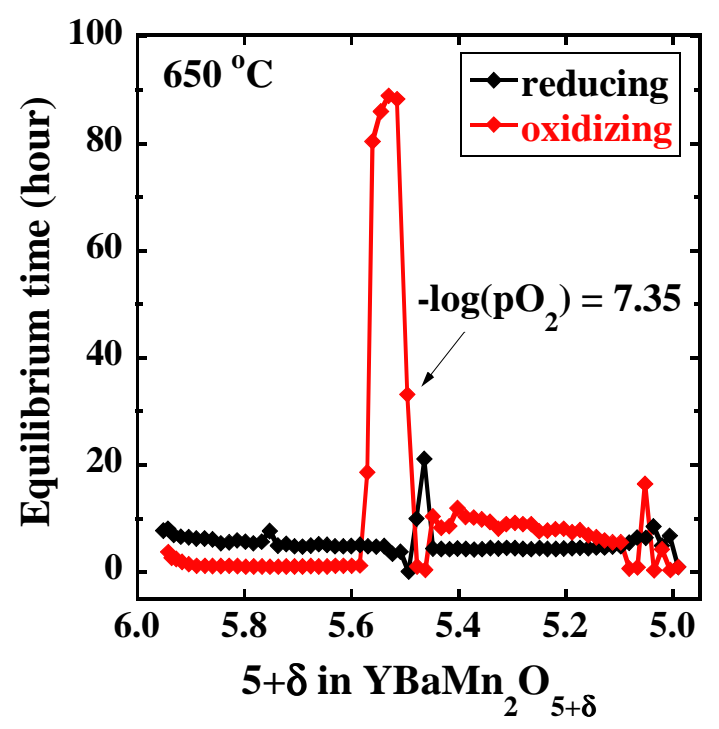

Figure 5: Equilibrium times as a function of oxygen non-stoichiometry for $\mathrm{YBaMn}_{2} \mathrm{O}_{5+\delta}$ at $650{ }^{\circ} \mathrm{C}$.

On reduction, equilibrium times were $\sim 5 \mathrm{~h}$ per point except in the vicinity of the interconversion of $\mathrm{O}_{5}$ and $\mathrm{O}_{5.5}$ where they were significantly longer $(\sim 15 \mathrm{~h}$ per point). This is consistent with the observation that $\mathrm{O}_{5.5}$ is not observed on rapid oxidation of $\mathrm{O}_{5}$ in oxygen (slow inter-conversion of $\mathrm{O}_{5}$ and $\mathrm{O}_{5.5}$. An unusual feature are the steps in that data that occur at $-\log$ $\mathrm{pO}_{2}=7.35,7.71$, and 7.77 at 650,700 , and $750{ }^{\circ} \mathrm{C}$ (Fig. 3(a-c)), respectively. The kinetics associated with these discontinuities are extremely slow. Eventually the data rejoin the curve obtained on reduction at 650 and $700{ }^{\circ} \mathrm{C}$ but at $750{ }^{\circ} \mathrm{C}$ it was necessary to relax the criterion for equilibrium to obtain a fully oxidized sample. The system is not completely reversible on reoxidation due to phase separation as evidenced by the slow kinetics. The oxide phases after the experiments at 700 and $750{ }^{\circ} \mathrm{C}$ were removed from the cell and analyzed by powder X-ray diffraction. The diffraction patterns confirmed that partial and complete decomposition to 
$\mathrm{BaMnO}_{3-\delta}$ and $\mathrm{YMnO}_{3}$ occurred at 700 and $750{ }^{\circ} \mathrm{C}$, respectively, as shown in Figure 6 for the product obtained at $750{ }^{\circ} \mathrm{C}$.

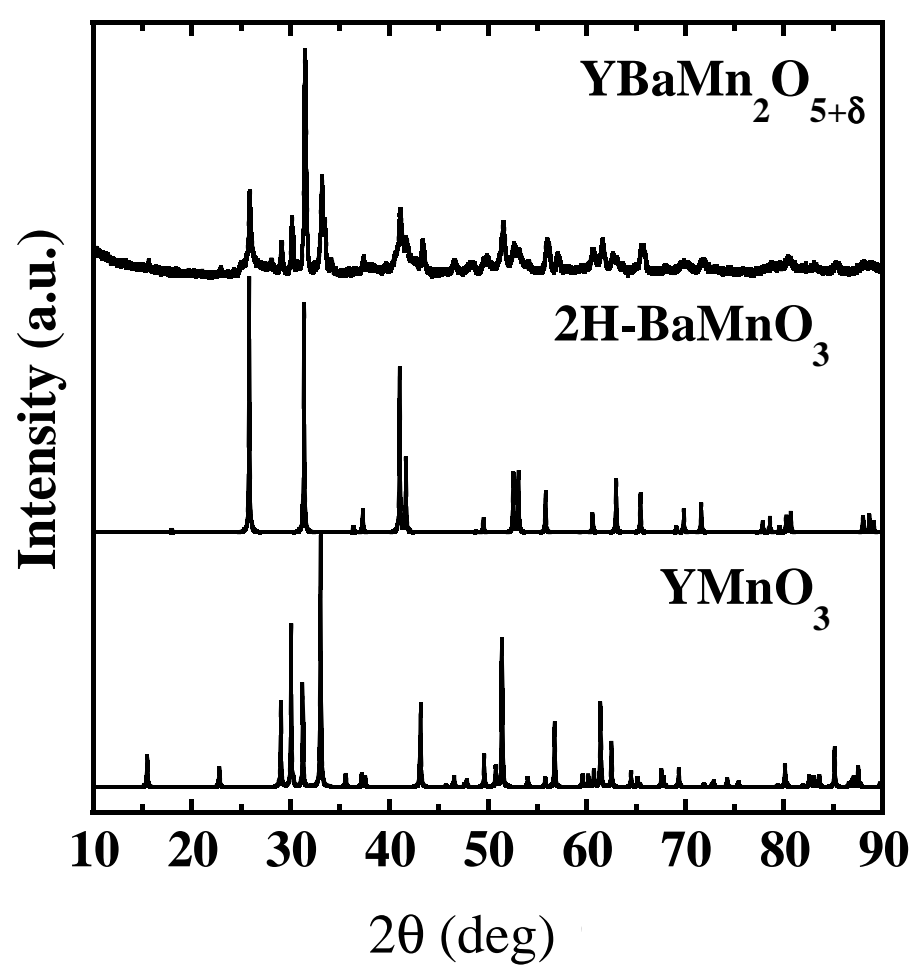

Figure 6: X-ray data for $\mathrm{YBaMn}_{2} \mathrm{O}_{5+\delta}$ collected after re-oxidation by Coulometric titration at 750 ${ }^{\circ} \mathrm{C}$, compared with the X-ray diffraction patterns of $2 \mathrm{H}-\mathrm{BaMnO}_{3}$ and $\mathrm{YMnO}_{3}$ obtained from the ICSD database.

At higher temperature $\left(800{ }^{\circ} \mathrm{C}\right)$ it was not possible to reach equilibrium in the reduction reaction starting at $\mathrm{O}_{6}$ because phase separation to $\mathrm{BaMnO}_{3-\delta}$ and $\mathrm{YMnO}_{3}$ occurred at the high $\mathrm{pO}_{2}$ and $800{ }^{\circ} \mathrm{C}$. Based on literature data ${ }^{56}$, we expect $\delta \approx 0$ for $\mathrm{BaMnO}_{3-\delta}$ and consequently the average Mn oxidation state and total oxygen content is the same for $\mathrm{YBaMn}_{2} \mathrm{O}_{6}$ and for the phase separated products at high $\mathrm{pO}_{2}(\sim 1$ atm). 


\subsection{Thermodynamics}

The partial molar free energy of oxygen atom $\left(\Delta \mu_{\mathrm{O}}\right)$ at equilibrium between the solid and the gas phase calculated from the reduction data in Figure 3 is shown in Figure 7. The data clearly show the existence of two two-phase regions corresponding to the reactions:

$$
\begin{aligned}
& 2 \mathrm{YBaMn}_{2} \mathrm{O}_{5.0}(\mathrm{~s})+1 / 2 \mathrm{O}_{2}(\mathrm{~g}) \rightarrow 2 \mathrm{YBaMn}_{2} \mathrm{O}_{5.5}(\mathrm{~s}) \\
& 10 / 3 \mathrm{YBaMn}_{2} \mathrm{O}_{5.5}(\mathrm{~s})+1 / 2 \mathrm{O}_{2}(\mathrm{~g}) \rightarrow 10 / 3 \mathrm{YBaMn}_{2} \mathrm{O}_{5.8}(\mathrm{~s})
\end{aligned}
$$

and the existence of a single phase with a range of stoichiometry above $\mathrm{YBaMn}_{2} \mathrm{O}_{5.8}$. At $700 \mathrm{C}$ and $750{ }^{\circ} \mathrm{C}, \mathrm{YBaMn}_{2} \mathrm{O}_{5.0}$ also appears to have a small range of non-stoichiometry ( $\sim 5.0$ to 5.1 see Table 3).

At $650{ }^{\circ} \mathrm{C}$, the average values of $\Delta \mu_{\mathrm{O}}$ in the two phase regions equal -131.00 and -28.60 $\mathrm{kJ} / \mathrm{mol}$ for oxidation from $\delta=0\left(\mathrm{YBaMn}_{2} \mathrm{O}_{5}\right)$ to $\delta=0.5\left(\mathrm{YBaMn}_{2} \mathrm{O}_{5.5}\right)$, and from $\delta=0.5$ $\left(\mathrm{YBaMn}_{2} \mathrm{O}_{5.5}\right)$ to $\delta \approx 0.8\left(\mathrm{YBaMn}_{2} \mathrm{O}_{5.8}\right)$, respectively, as shown in Fig. 7 (a). Both reactions are exergonic. In addition, the partial molar free energy on oxidation is less negative with increasing temperature as shown in Fig 7 (b) and (c). The value of $\Delta \mu_{\mathrm{O}}$ in oxidation from $\delta=0\left(\mathrm{YBaMn}_{2} \mathrm{O}_{5}\right)$ to $\delta=0.5\left(\mathrm{YBaMn}_{2} \mathrm{O}_{5.5}\right)$ is $\Delta \mu_{\mathrm{O}}=-124.97 \mathrm{~kJ} / \mathrm{mol}$ at $700{ }^{\circ} \mathrm{C}$ and $\Delta \mu_{\mathrm{O}}=-119.34 \mathrm{~kJ} / \mathrm{mol}$ at $750{ }^{\circ} \mathrm{C}$. For oxygen intake from $\delta=0.5\left(\mathrm{YBaMn}_{2} \mathrm{O}_{5.5}\right)$ to $\delta \approx 0.8\left(\mathrm{YBaMn}_{2} \mathrm{O}_{5.8}\right), \Delta \mu_{\mathrm{O}}$ becomes less negative from $-26.39 \mathrm{~kJ} / \mathrm{mol}$ at $700^{\circ} \mathrm{C}$ to $-24.64 \mathrm{~kJ} / \mathrm{mol}$ at $750^{\circ} \mathrm{C}$. Plots of $\mathrm{R} / 2 \times \ln \left(\mathrm{pO}_{2}\right)$ versus $1 / \mathrm{T}$ and $\mathrm{RT} / 2 \times \ln \left(\mathrm{pO}_{2}\right)$ versus $\mathrm{T}$ are linear indicating that the enthalpy and entropy are constant in this narrow temperature range. The values for the changes in enthalpy and entropy are -238.7 $\mathrm{kJmol}^{-1}$ and $-116.6 \mathrm{Jmol}^{-1} \mathrm{~K}^{-1}$ for the conversion of $\mathrm{O}_{5}$ to $\mathrm{O}_{5.5}$ (reaction 1 ), and $-39.2 \mathrm{kJmol}^{-1}$ and $23.8 \mathrm{Jmol}^{-1} \mathrm{~K}^{-1}$ for the conversion of $\mathrm{O}_{5.5}$ to $\mathrm{O}_{5.8}$ (reaction 2). 

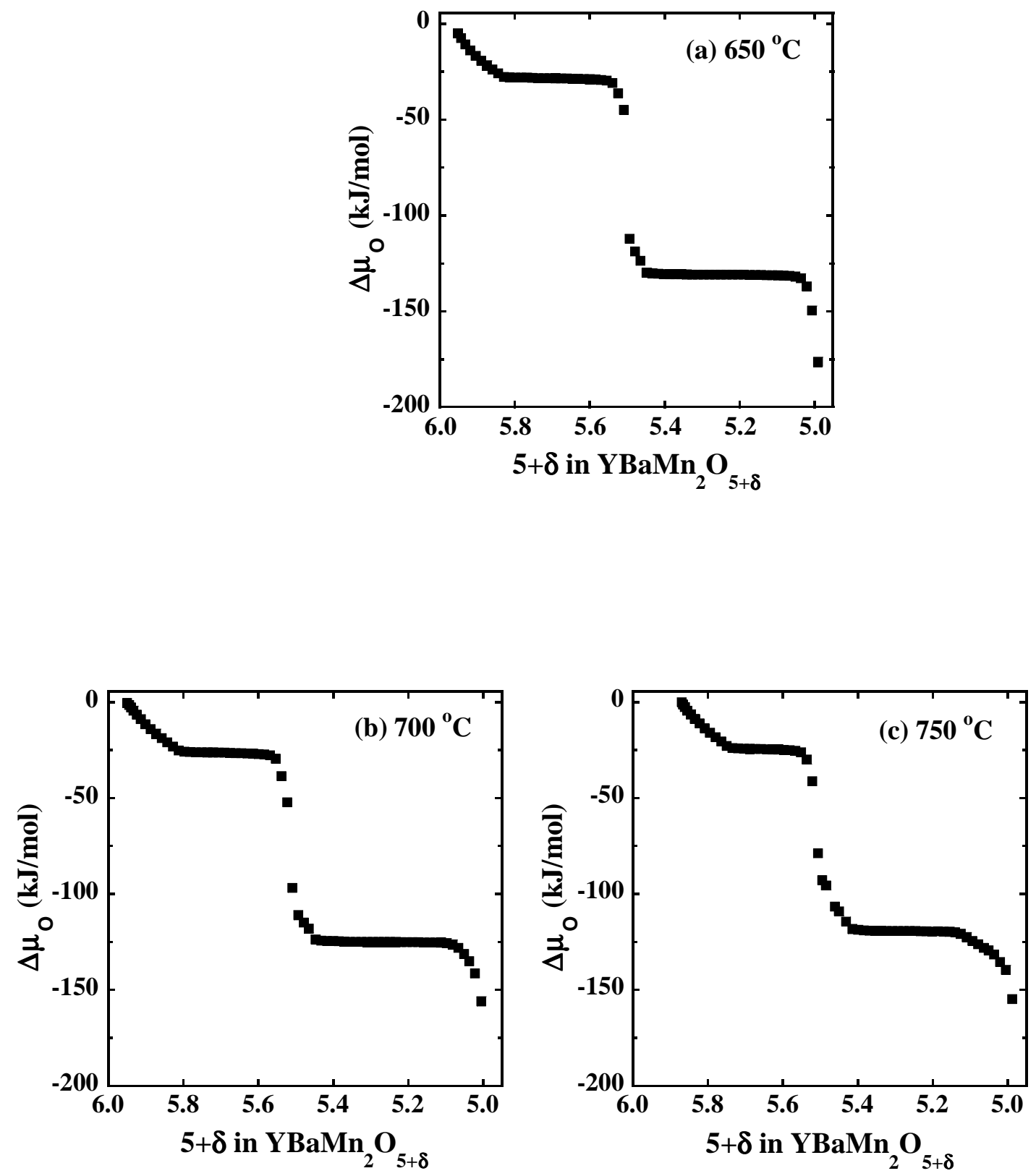

Figure 7: Partial molar free energy of oxygen atom $\left(\Delta \mu_{O}\right)$ as a function of oxygen content for $\mathrm{YBaMn}_{2} \mathrm{O}_{5+\delta}$ at (a) $650{ }^{\circ} \mathrm{C}$, (b) $700{ }^{\circ} \mathrm{C}$ and (c) $750{ }^{\circ} \mathrm{C}$.

\section{Conclusions}

The A site-ordered double-perovskite $\mathrm{YBaMn}_{2} \mathrm{O}_{5+\delta}$ was successfully synthesized by solid state reaction under a reducing atmosphere. Thermogravimetric measurements show good oxygen 
uptake/release ability of this compound at moderate temperatures in agreement with previous work. The oxygen storage capacity is $\sim 2200 \mu \mathrm{mol}-\mathrm{O} / \mathrm{g}$ and is higher than that of $\mathrm{Ce}_{1-\mathrm{x}} \mathrm{Zr}_{\mathrm{x}} \mathrm{O}_{2+\delta}$. The oxygen non-stoichiometry of $\mathrm{YBaMn}_{2} \mathrm{O}_{5+\delta}$ was determined as a function of $\mathrm{pO}_{2}$ and temperature by using a Coulometric titration method. Only three distinct phases of $\mathrm{YBaMn}_{2} \mathrm{O}_{5+\delta}$ with $\delta \approx 0,0.5$ and $\sim 1$ are observed during the oxidation/reduction process. The phase transitions shift to higher $\mathrm{pO}_{2}$ as the temperature increases. The partial molar free energies $\left(\Delta \mu_{\mathrm{O}}\right)$ corresponding to the oxidation of $\mathrm{YBaMn}_{2} \mathrm{O}_{5}$ to $\mathrm{YBaMn}_{2} \mathrm{O}_{5.5}$ and of $\mathrm{YBaMn}_{2} \mathrm{O}_{5.5}$ to $\mathrm{YBaMn}_{2} \mathrm{O}_{5.8}$ were determined. The value of $\Delta \mu_{\mathrm{O}}$ in both oxidation steps becomes less negative with increasing temperature. The $\mathrm{YBaMn}_{2} \mathrm{O}_{5+\delta}$ compound has possible applications in oxygen storage technology but based on the present results, the instability with respect to decomposition to $\mathrm{BaMnO}_{3-\delta}$ and $\mathrm{YMnO}_{3}$ at high $\mathrm{pO}_{2}$ and temperature may be of some concern for practical applications.

\section{Acknowledgements}

The work was supported by the Robert A. Welch Foundation (Grant No. E-0024, TM; TGA measurements) and the U.S. Department of Energy (U.S. DOE), Office of Basic Energy Sciences Division of Materials Sciences and Engineering (under Award No. DE-SC0001284, KJ, WG, AJJ; experiments and analysis).

\section{References}

(1) Kašpar, J.; Fornasiero, P. J. Solid State Chem. 2003, 171, 19-29.

(2) Yang, Z.; Lin, Y. S.; Zeng, Y. Ind. Eng. Chem. Res. 2002, 41, 2775-2784.

(3) Wei, Y.; Wang, H.; He, F.; Ao, X.; Zhang, C. J. Nat. Gas Chem. 2007, 16, 6-11.

(4) Li, K.; Wang, H.; Wei, Y. J. Chem. 2013, Article ID 294817.

(5) Wang, K.; Yu, Q.; Qin, Q. J. Therm. Anal. Calorim. 2013, 112, 747-753. 
(6) Bhavsas, S.; Veser, G. RSC Adv.2014, 4, 47254-47267.

(7) Parkkima, O.; Yamauchi, H.; Karppinen, M. Chem. Mater.2013, 25 (4), 599-604.

(8) Nagai, Y.; Yamamoto, T.; Tanaka, T.; Yoshida, S.; Nonaka, T.; Okamoto, T.; Suda, A.; Sugiura, M. Catal. Today 2002, 74, 225-234.

(9) Damyanova, S.; Pawelec, B.; Arishtirova, K.; Martinez Huerta, M.V.; Fierro, J.L.G. Appl. Catal. A: Gen. 2008, 337, 86-96.

(10) DiMonte, R.; Fornasiero, P.; Graziani, M.; Kašpar, J. J. Alloys Compd. 1998, 275-277, $877-885$.

(11) He, H.; Dai, H. X.; Au, C. T. Catal. Today 2004, 90, 245-254.

(12) Kašpar, J.; Fornasiero, P.; Hickey, N. Catal. Today 2003, 77, 419-449.

(13) Otsuka, K.; Wang, Y.; Nakamura, M. Appl. Catal. A: Gen. 1999, 183, 317-324.

(14) Pantu, P.; Kim, K.; Gavalas, G. R. Appl. Catal. A: Gen. 2000, 193, 203-214.

(15) Sugiura, M. Catal. Surv. Asia 2003, 7 (1), 77-87.

(16) Hao, Y.; Yang, C.-K.; Haile, S. M. Chem. Mater. 2014, 26, 6073-6083 and references therein.

(17) Karppinen, M.; Yamauchi, H.; Otani, S.; Fujita, T.; Motohashi, T.; Huang, Y.-H.; Valkeapää, M.; Fjellvåg, H. Chem. Mater. 2006, 18, 490-494.

(18) Remsen, S.; Dabrowski, B. Chem. Mater. 2011, 23, 3818-3827.

(19) Motohashi, T.; Hirano, Y.; Masubuchi, Y.; Oshima, K.; Setoyama, T.; Kikkawa, S. Chem. Mater. 2013, 25, 372-377.

(20) Hervieu, M.; Guesdon, A.; Bourgeois, J.; Elkaïm, E.; Poienar, M.; Damay, F.; Rouquette, J.; Maignan, A.; Martin, C. Nat. Mater. 2013, 13, 74-80. 
(21) Motohashi, T.; Ueda, T.; Masubuchi, Y.; Takiguchi, M.; Setoyama, T.; Oshima, K.; Kikkawa, S. Chem. Mater. 2010, 22, 3192-3196.

(22) Motohashi, T.; Takahashi, T.; Kimura, M.; Masubuchi, Y.; Kikkawa, S.; Kubota, Y.; Kobayashi, Y.; Kageyama, H.; Takata, M.; Kitagawa, S.; Matsuda, R. J. Phys. Chem. C 2015, 119, 2356-2363.

(23) Motohashi, T.; Ueda, T.; Masubuchi, Y.; Kikkawa, S. J. Ceram. Soc. Jpn. 2011, 119 (11), 894-897.

(24) Motohashi, T.; Ueda, T.; Masubuchi, Y.; Kikkawa, S. J. Phys. Chem. C 2013, 117, 12560 12566.

(25) Ávila-Brande, D.; King, G.; Urones-Garrote, E.; Subakti; Llobet, A.; García-Martín, S. Adv. Funct. Mater. 2014, 24, 2510-2517.

(26) Caignaert, V.; Millange, F.; Domengès, B.; Raveau, B. Chem. Mater. 1999, 11, 930-938.

(27) Klimkowicz, A.; Świerczek, K.; Takasaki, A.; Molenda, J.; Dabrowski, B. Mater. Res. Bull. 2015, 65, 116-122.

(28) Klimkowicz, A.; Świerczek, K.; Zheng, K.; Baranowska, M.; Takasaki, A.; Dabrowski, B. Solid State Ionics 2014, 262, 659-663.

(29) Klimkowicz, A.; Zheng, K.; Fiolka, G.; Świerczek, K. CHEMIK 2013, 67 (12), 11991206.

(30) Millange, F.; Caignaert, V.; Domengès, B.; Raveau, B. Chem. Mater. 1998, 10, 19741983.

(31) Motohashi, T.; Kimura, M.; Inayoshi, T.; Ueda, T.; Masubuchi, Y.; Kikkawa, S. Dalton Trans. 2015, Advance Article DOI: 10.1039/C4DT03863K. 
(32) Nakajima, T.; Kageyama, H.; Yoshizawa, H.; Ohoyama, K.; Ueda, Y. J. Phys. Soc. Jpn. 2003, 72 (12), 3237-3242.

(33) Nakajima, T.; Kageyama, H.; Yoshizawa, H.; Ueda, Y. J. Phys. Soc. Jpn. 2002, 71 (12), 2843-2846.

(34) Nakajima, T.; Yoshizawa, H.; Ueda, Y. J. Phys. Soc. Jpn. 2004, 73 (8), 2283-2291.

(35) Sengodan, S.; Choi, S.; Jun, A.; Shin, T. H.; Ju, Y-W.; Jeong, H. Y.; Shin, j.; Irvine, J. T. S.; Kim, G. Nat. Mater. 2015, 14 (2), 205-209.

(36) Świerczek, K.; Klimkowicz, A.; Niemczyk, A.; Olszewska, A.; Rząsa, T.; Molenda, J.; Takasaki, A. Funct. Mater. Lett. 2014, 7 (6), 1440004.

(37) Świerczek, K.; Klimkowicz, A.; Zheng, K.; Dabrowski, B. J. Solid State Chem. 2013, 203, 68-73.

(38) Taksin, A. A.; Ando, Y. Phys. Rev. Lett. 2007, 98, 207201.

(39) Taksin, A. A.; Lavrov, A. N.; Ando, Y. Appl. Phys. Lett. 2005, 86, 091910.

(40) Troyanchuk, I. O.; Trukhanov, S. V.; Chobot, G. M.; Szymczak, H. Phys. Solid State $\mathbf{2 0 0 3}, 45$ (2), 276-282.

(41) Troyanchuk, I. O.; Trukhanov, S. V.; Szymczak, G. Crystallogr. Rep. 2002, 47 (4), 658665.

(42) Ueda, Y.; Nakajima, T. J. Phys.: Condens. Matter 2004, 16, S573-S583.

(43) Williams, A. J.; Attfield, J. P. Phys. Rev. B. 2002, 66, 220405.

(44) Williams, A. J.; Attfield, J. P. Phys. Rev. B. 2005, 72, 184426.

(45) Beales, T. P.; M $\square \operatorname{lgg}$, M.; Jutson, J.; Friend, C. M. Phys. Stat. Sol. 1997, (a) 161, 271 282. 
(46) Chapman, J. P.; Attfield, J. P.; Molgg, M.; Friend, C. M.; Beales, T. P. Angew. Chem., Int. Ed. 1996, 35, 2482-2484.

(47) Karppinen, M.; Okamoto, H.; Fjellva $\square$ g, H.; Motohashi, T.; Yamauchi, H. J. Solid State Chem. 2004, 177, 2122-2128.

(48) Mcallister, J. A.; Attfield, J. P. J. Mater. Chem. 1998, 8, 1291-1294.

(49) Perca, C.; Pinsard-Gaudart, L.; Daoud-Aladine, A.; Fernández-Díaz, M. T.; RodríguezCarvajal, J. Chem. Mater. 2005, 17 (7), 1835-1843.

(50) Park, C. Y.; Jacobson, A. J. J. Electrochem. Soc. 2005, 152, J65-J73.

(51) Yoo, J.; Park, C. Y.; Jacobson, A. J. Solid State Ionics 2004, 175, 55-58.

(52) Kosuge, K. Chemistry of Non-Stoichiometric Compounds; Oxford University Press, Oxford, 1994.

(53) Park, J. H.; Blumenthal, R. N. J. Electrochem. Soc. 1989, 136, 2867-2876.

(54) Millange, F.; Suard, E.; Caignaert, V.; Raveau, B. Mater. Res. Bull. 1999, 34 (1), 1-9.

(55) Williams, A. J.; Attfield, J. P. Phys. Rev. 2005, B 72, 024436.

(56) Negas, T.; Roth, R. S. J. Solid State Chem. 1971, 3, 323-339. 


\section{Graphical Abstract}
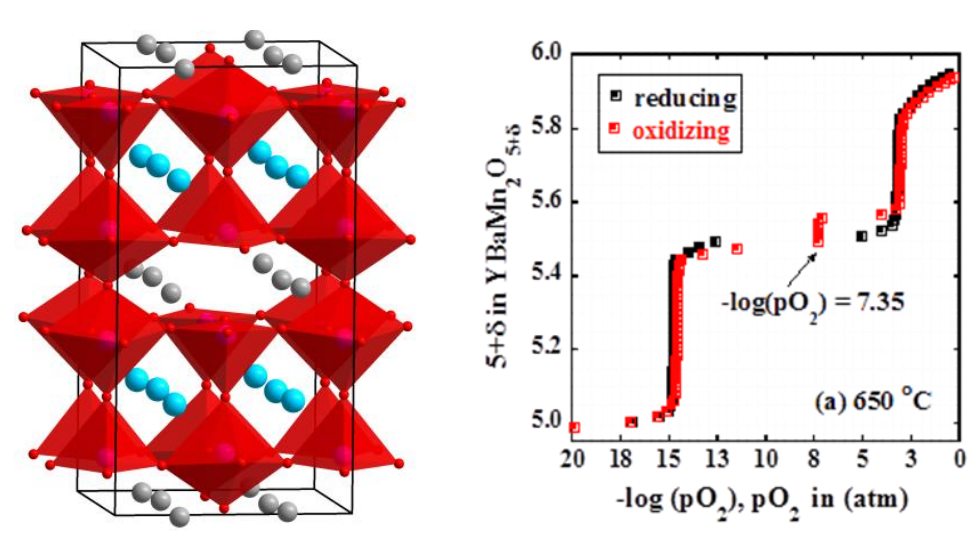

\section{Graphical Abstract}

\section{Graphical Abstract}

